\title{
Polar bears (Ursus maritimus) mating during late June on the pack ice of northern Svalbard, Norway
}

\author{
Thomas G. Smith ${ }^{1}$ \& Jon Aars ${ }^{2}$ \\ ${ }^{1}$ Eco Marine Corporation, 5694 Camp Comfort Rd., Beaulac-Garthby, Quebec GOY1B0, Canada \\ ${ }^{2}$ Norwegian Polar Institute, Fram Centre, PO Box 6606 Langnes, NO-9296 Tromsø, Norway
}

\author{
Keywords \\ Polar bear; mating season; \\ mating behaviour; Svalbard; Arctic.

\section{Correspondence} \\ Jon Aars, Norwegian Polar Institute, \\ Fram Centre, PO Box 6606 Langnes, \\ NO-9296 Tromsø, Norway. \\ E-mail: jon.aars@npolar.no
}

\begin{abstract}
Polar bears are seasonal breeders and typically mate from late March to early May. Implantation is, however, delayed until autumn, which can allow plasticity in the date of mating. As for other seasonal breeders, a rapid return to estrus after the loss of dependent offspring can be expected, even into the summer. A few earlier observations and dissections of dead animals suggest that polar bears are able to mate in summer. We report on a mating incident on 29 June 2014, the first documented mating this late in the season among wild polar bears. The female had lost her dependent cub during the period prior to the mating event. We speculate that she lost this cub late in the mating season, entered estrus and successfully mated in late June.
\end{abstract}

As is common among mammals, seven out of the eight bear species exhibit distinct birth and mating seasonality (Spady et al. 2007). Almost 100 mammal species, in seven mammalian orders, are known to undergo delayed implantation, in which blastocyst cell division is arrested or very slow (Renfree \& Shaw 2000). Seasonality in mating and parturition, combined with delayed implantation, allows species living in environments with strong seasonality in environmental factors to time reproductive events to optimize reproductive success. Brown bears (Ursus arctos) and polar bears (U. maritimus) usually mate in summer and spring, respectively (Spady et al. 2007). There remains some uncertainty about the timing of the mating season of polar bears (Wiig et al. 1992; Rosing-Asvid et al. 2002). A limited number of observations of polar bear mating have been reported (Hagen 1975; Ramsay \& Stirling 1986; Stirling 2012). The main evidence of the duration of the breeding season comes from examining male and female reproductive organs collected from hunted animals. Male-female pairs are observed mainly in spring; in Svalbard (Norwegian Arctic) usually from late March to early May (Wiig et al. 1992; Derocher et al. 2010). However, Lønø (1970) concluded from histological examinations of ovaries and testes that June might be the peak mating period. He further stated that mating likely occurs into July. Although it is now commonly agreed that most mating takes place in spring, his findings warrant further research to better understand how flexible polar bears are regarding mating at later dates, for example, when cubs are lost in late spring or early summer.

\section{Results and discussion}

At 16:10 Norwegian time $(-2 \mathrm{~h}=\mathrm{GMT})$ on 29 June 2014, two polar bears were sighted approximately one nautical mile from the tourist ship MS Expedition. These were located at approximately $80^{\circ} 10.190^{\prime} \mathrm{N}$ and $015^{\circ}$ 53.40' E at the northern end of Hinlopen Strait, Svalbard.

The bears were found on a large floe of floating unbroken smooth first-year ice, which was approximately $2 \mathrm{~km}$ long (east to west) by $800-900 \mathrm{~m}$ wide (north to south). At the time of the first sighting, the two bears were quite active, and it became clear that the largest animal was pursuing the smaller one. At 16:15, as we approached to within $700-800 \mathrm{~m}$ of the bears, we ascertained that the large male had mounted the smaller female, who was wearing an iridium satellite GPS collar (Telonics, Mesa, AZ, USA). For the next 65 min, the two bears were tied together and actively copulating (Fig. la). The female would occasionally struggle, but the male remained on her, holding her with his front legs wrapped tightly around 


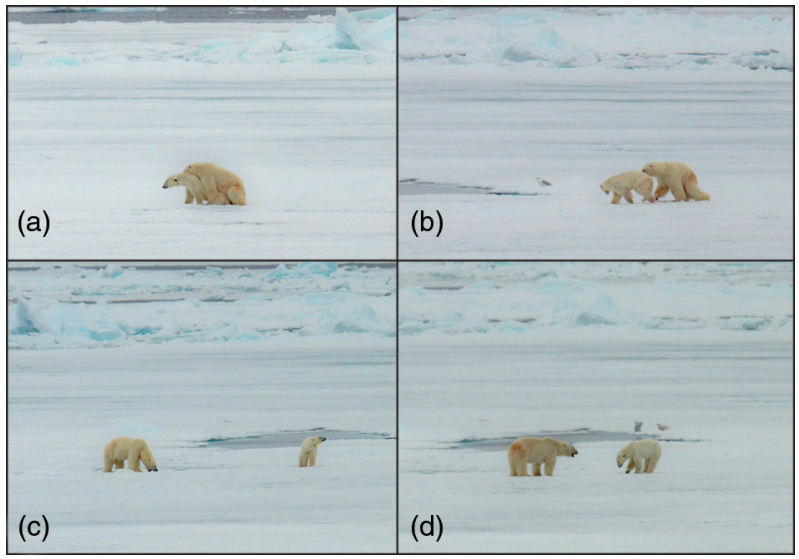

Fig. 1 (a) The two bears observed mating, (b) the bears just after separation, (c) the male licking snow after mating and (d) the male herding the female.

her body and making pelvic thrusts. The bears separated at 17:20, but remained in close proximity, moving slowly together (Fig. lb). The male was seen to eat snow a few times while following the female (Fig. 1c), who would occasionally lie down. At 17:35, both bears, the female in the lead, began to move north across the smooth unbroken surface of the large floe. After a short distance, the male began to herd (Ramsay \& Stirling 1986; Stirling 2012) the female by making short charges toward her from a maximum distance of approximately $100 \mathrm{~m}$ (Fig. 1d). This resulted in turning her around, back toward the south, and keeping her in the centre of the floe. This was repeated at least three times, which possibly indicated that the male was trying to monopolize the female.

The female lay down at 18:11 and remained in the same position on the ice floe. After a few minutes, the male lay down within a few metres of her. The ship remained in position until 19:30, then moved south away from the bears, who remained lying down on the ice. During the whole observation period, there was no sign from the bears that they were reacting in any way to the presence of the ship.

The female bear (N23937) was identified from the satellite tag, which gave its GPS position on the date and time of the sighting. She was first captured in April 2008, during the annual capture-recapture programme of the Norwegian Polar Institute. Her size and the cementum lines in a rudimentary tooth extracted during her capture indicated that her birth year was 2005 (likely uncertainty \pm 1 year; Christensen-Dahlsgaard et al. 2010). This female, which habitually occupies the area of north-west Spitsbergen, was recaptured alone in April 2011 and in April 2012. In April 2013, at the estimated age of eight years, she was with a cub of the year. On 31 August 2013, this mother and cub were again captured, and at that time the mother was equipped with the iridium telemetry collar.

The mother and her cub were again captured on 7 April 2014. At that time, the yearling cub measured $47 \mathrm{~kg}$. This is the lowest body weight measured among 41 yearling cubs in the spring from 1989 to 2014 in Svalbard (mean $77.4 \mathrm{~kg}$, 95\% confidence interval: $70.7 \mathrm{~kg}-$ $84.0 \mathrm{~kg}$ ). At $162 \mathrm{~kg}$, the mother had lost $47 \mathrm{~kg}$ since the previous autumn. She did not seem to be lactating. We flew over the area where the bears had been handled on both 12 and 23 April, but they were then not seen in the area. When the mother was again observed, mating, on 29 June, the cub was not seen anywhere close despite prolonged observation of the area of floating pack ice.

In the winter of $2013 / 14$, sea ice did not form in the fjords of northern Spitsbergen as it does in most years. The first ice was present about late March to early April. This may be part of the reason why the female with her yearling was seen to be in rather bad condition in early April, and may have contributed to the later death of the yearling. We hypothesize that this mother lost her yearling after the main mating season, maybe in late May or in June, and that mating in summer was a viable option to ensure pregnancy and reproduction in the coming winter. To optimize reproductive success, among species with seasonal breeding, a rapid return to estrus after a loss of still dependent offspring should be expected among healthy mothers (Wolff \& MacDonald 2004).

Limited evidence, such as the present observation of mating, suggests that the reproductive season of polar bears might be longer than has been documented in the literature. Given the obvious biases in the data from reproductive tracts of harvested bears on which the mating season has previously been defined (e.g., Rosing-Asvid et al. 2002), it is reasonable to consider that mating might occur well into summer. Examination of reproductive organs from culled animals in Svalbard has indicated that males and females may be receptive for mating well into the summer (Lønø 1970). Another observation of a summer mating event, also in Svalbard, was on 20 June 1924 (Kræmer 1940), when a mating pair was observed and shot. The female had swollen labia indicating she was sexually receptive, and Kræmer states he had seen this on many occasions among adult females culled from mid-May to late June.

Delayed implantation may be obligate or facultative, and the mechanisms of onset and escape differ widely among mammal species (Lopes et al. 2004). The level of plasticity in when females may successfully mate will likely also vary accordingly. Our observation fits well with recent reports of brown bears mating outside their summer 
mating season, well into autumn (Nevin \& Gilbert 2005; Kohira \& Mori 2010; Tosoni et al. 2011; Steyaert et al. 2012).

Polar bears have delayed implantation, and nidation is likely initiated by change in daylight length (Palmer et al. 1988; Wiig et al. 1992). Distinct mating and birth seasons have evolved among bear species during the Pliocene or Pleistocene, periods with increased seasonality of food availability (Spady et al. 2007). The delay in foetal development probably serves as a mechanism to synchronize birthing in polar bears with that of their principal prey species, the ringed seal (Pusa hispida; McLaren 1958).

This flexible characteristic of the reproductive cycle would give polar bears that have lost a dependent offspring an opportunity to mate later in the same year, and optimize reproductive fitness. It is likely that some cub mortality occurs in early summer following the long winter months when food is scarce and low temperatures are energetically demanding. It is also possible, however, that infanticide can be a male reproductive strategy in polar bears (Taylor et al. 1986).

In areas of the Arctic such as the Svalbard Archipelago, where there is a high interannual variability in the amount of both land-fast and pack ice, an extended period of mating could be seen to offer a net gain in reproductive potential. An extended mating season might also serve as an important adaptive mechanism for polar bears living in areas of the Arctic which could undergo reductions or changes in sea-ice regimes (Comiso 2002).

\section{Acknowledgements}

We thank Kevin Morgan, who first spotted the mating bears, Frank S. Todd and Lauren Farmer for the photographic documentation and Susan Adie, the Expedition Leader for $G$ Adventures, for allowing us the opportunity to thoroughly document this unique event. The careful approach of the ship by Captain Giovanni Biasutti allowed us to observe this event without disrupting the behaviour of the bears. We also thank Magnus Andersen and Rupert Krapp for their involvement in the capturerecapture work that provided reproductive and spaceuse data for the female bear. The governor of Svalbard and the Norwegian Animal Health Authority granted approval for this work.

\section{References}

Christensen-Dalsgaard S.N., Aars J., Andersen M., Lockyer C. \& Yoccoz N.G. 2010. Accuracy and precision in estimation of age of Norwegian Arctic polar bears (Ursus maritimus) using dental cementum layers from known age individuals. Polar Biology 33, 589-597.
Comiso J.C. 2002. A rapidly declining perennial sea ice cover in the Arctic. Geophysical Research Letters 29, 1956.

Derocher A., Andersen M., Wiig Ø. \& Aars J. 2010. Sexual dimorphism and the mating ecology of polar bears (Ursus maritimus) at Svalbard. Behavioral Ecology and Sociobiology 64, 939-946.

Hagen G. 1975. An observation of polar bear mating in Svalbard. Norsk Polarinstitutt Årbok 195, 532-533.

Kohira M. \& Mori S.-y. 2010. Reported mating of Hokkaido brown bear in autumn. Ursus 21, 192-194.

Kræmer W. 1940. Fangstlivet i Nordishavet og på land på Svalbard i 45 år. (Hunting in the northern Arctic Ocean and in Svalbard for 45 years.) Unpubl. ms. Available at Norwegian Polar Institute Library, magazine code DAG-192.

Lønø O. 1970. The polar bear (Ursus maritimus Phipps) in the Svalbard area. Norsk Polarinstitutt Skrifter 149. Tromsø: Norwegian Polar Institute.

Lopes F.L., Desmarais J.A. \& Murphy B.D. 2004. Embryonic diapause and its regulation. Reproduction 128, 669-678.

McLaren I.A. 1958. The biology of the ringed seal (Phoca hispida Schreber) in the eastern Canadian Arctic. Bulletin of the Fisheries Research Board of Canada 118, 28-58.

Nevin O.T. \& Gilbert B.K. 2005. Observations of autumn courtship and breeding in brown bears, Ursus arctos, from coastal British Columbia. Canadian Field-Naturalist 119, 449-450.

Palmer S.S., Nelson R.A., Ramsay M.A., Stirling I. \& Bahr J.M. 1988. Annual changes in some sex steroids in male and female black bears (Ursus americanus) and polar bears (Ursus maritimus). Biology of Reproduction 38, 1044-1050.

Ramsay M.A. \& Stirling I. 1986. On the mating system of polar bears. Canadian Journal of Zoology 64, 2142-2151.

Renfree M.B. \& Shaw G. 2000. Diapause. Annual Review of Physiology 62, 353-375.

Rosing-Asvid A., Born E.W. \& Kingsley M.C.S. 2002. Age at sexual maturity of males and timing of the mating season of polar bears (Ursus maritimus) in Greenland. Polar Biology 25, 878-883.

Spady T.J., Lindburg D.G. \& Durrant B.S. 2007. Evolution of reproductive seasonality in bears. Mammal Review 37, 21-53.

Steyaert S.M.J.G., Endrestol A., Hacklaender K., Swenson J.E. \& Zedrosser A. 2012. The mating system of the brown bear Ursus arctos. Mammal Review 42, 12-34.

Stirling I. 2012. Polar bears. The natural history of a threatened species. Markham, Ontario: Fitzhenry and Whiteside Publishers.

Taylor M., Larsen T.S. \& Schweinsburg R.E. 1986. Observations of intraspecific aggression and cannibalism in polar bears. Arctic 38, 303-309.

Tosoni E., Palozzi G., Trella E., Boitani L. \& Ciucci P. 2011. A case of autumn mating in the Apennine brown bear (Ursus arctos marsicanus). Hystrix, the Italian Journal of Mammalogy $22,349-353$.

Wiig Ø., Gjertz I., Hansson R. \& Thomassen J. 1992. Breeding behaviour of polar bears in Hornsund. Polar Record 28, $157-159$.

Wolff J.O. \& Macdonald D.W. 2004. Promiscuous females protect their offspring. Trends in Ecology $\theta$ Evolution 19, 127-134. 